EASTERN REVIEW 2020, T. 9

\author{
Marek Barański \\ (iD) https://orcid.org/0000-0002-6986-7994 \\ University of Silesia, Katowice, Poland \\ Faculty of Social Sciences, Institute of Political Sciences \\ e-mail: marek.baranski@us.edu.pl
}

\title{
The political party system in Slovakia in the era of Mečiarism \\ The experiences of the young democracies of central European countries
}

\begin{abstract}
This article aims to reconstruct the functioning of political parties that was present during the establishment of the foundations of the democratic system and political practice, from the "Velvet Revolution" to the creation of a competitive party system with a dominant political party - Movement for Democratic Slovakia (HZDS) set up by Vladimir Mečiar; who served as prime minister in the years 1993-1998 (including a hiatus in 1994) greatly affecting the state internal and international policy, and held the post of the sole chairman of the party until its dissolution. V. Mečiar's rule was marked by the interweaving of the elements of the wave of democratization with the reverse wave of de-democratization. The pro-democratic and undemocratic tendencies displayed by Mečiar were determined - apart from objective factors - by the personality traits of the prime minister: his commanding and charismatic leadership style, authoritarianism, making public decisions in a ruthless manner devoid of impartiality, or violations of democratic norms and values. Apart from its scientific purpose, this article may also fulfil a practical function allowing the possibility of using the research findings in social practice/politics.
\end{abstract}

Keywords: Slovakia, Vladimir Mečiar, party system, democracy, political party.

\section{Introduction}

The research issues of this article focus on the processes of democratization of central European countries as part of the third Huntingtonian wave of democratization (Huntington, 2009). Samuel Huntington's concept developed from the observation 
of the political phenomena of 1974-1990. It was noted that in dozens of countries which were moving from undemocratic to democratic political systems the process was marked by the coexistence of a wave of democratization and a reverse wave of de-democratization. Such phenomena and processes occur in all countries, although more frequently in young democracies. The third wave of democratization includes a regional group of countries with geopolitical features that greatly encourage comparative studies and allow for the extension of research methods and tools. This in turn increases the quality of research results as regards the internalization of the system of values and democratic institutions, as well as the level of the consolidation of the democratic system. The added value of the evaluation of comparative studies lies in their utilitarian function, which may be applied to social practice.

The thirty-year period of the democratization of the countries of Central Europe is marked by the diversity of the phases of the implementation of the democratic system and the advancement of the system's consolidation process. The systemic transformation was shaped by a group of countries that initiated changes in the region, with Poland at the forefront and Czechoslovakia and Hungary following its footsteps. The democratization process covered all the aforementioned countries, although separatist tendencies quickly emerged in Slovakia, which ultimately led to the breakup of the federation. The democratization of 'Czechoslovakian' Slovakia was consequently extended to include sovereign state-building.

The democratization of the Czechoslovakian Federal Republic was initiated by the "Velvet Revolution" which, contesting the authoritarian regime of real socialism, laid the foundations for parliamentary democracy and a market economy.

This article aims to investigate the role of political parties in the process of building the foundations for a democratic system and political practice based on the standards of the democratic legal state of Slovakia, from the "Velvet Revolution" to the creation of a competitive and hybrid party system with a dominant political party - Movement for Democratic Slovakia (HZDS) - which in the years 1992-1998 greatly affected the state internal and external policy. The research objective will be achieved by way of obtaining answers to the following questions:

- what factors contributed to the slowdown of the democratization process after the success of the first democratic elections in 1990?

- what caused the split of the political movement "Public Against Violence", which led to the formation of the Movement for Democratic Slovakia?

- what phenomena depreciated the stages of the waves of democratization and thus marked the era of Mečiarism?

- what role did Vladimir Mečiar's commanding and charismatic leadership style play in the creation and functioning of the authoritarian system of governance?

The leading theory for the description and assessment of the democratization process in Eastern European countries is the concept of a "wave-like" transition from undemocratic to democratic states, accompanied by the coexistence of waves of progress (democracy) and reverse waves of de-democratization. The thirty-year 
period of democratization in Poland, Czechoslovakia (the Czech Republic and Slovakia) and Hungary indicates significant differences in the balance between pro-democratic arguments and de-democratization. The conceptual layer of this article will be strengthened by the category of consolidated democracy as a political system in which democratic mechanisms operate for a relatively long period of time without breakdown. In order to verify the level of advancement of the democratization process, balancing of the waves of democratization and reverse waves, as well as the level of the consolidation of the party system, the following research methods were used: systemic, comparative, neo-institutional and analysis of documents, party manifestos and statistical data.

\section{From the Velvet Revolution to a hybrid party system}

The democratization of Slovakia initiated by the "Velvet Revolution" (Slovak: Neźna revolucia) within the Czech and Slovak Federation went through many phases, starting with the mass social protest of 17 November 1989 organized in Prague, followed by a meeting of five hundred intellectuals, artists and political figures held in Bratislava two days later. The rally of residents of the Slovak capital supported the Prague strike and the creation of the political movement Public Against Violence (Verejnost proti nasiliu, VPN). VPN was established by a group of founders (Jan Budaj, Martin Butora, Fedor Gal, Milan Kňažko, Jozef Kućerak and Peter Zajac), and on 20 November 1989 it made a statement rejecting violence in political, cultural and public life, demanding pluralism, freedom of the press, mass media openness, and release of political prisoners. On the same day, the first large meeting took place (attended by popular Kn̆ažko) where the establishment of the movement, with priority on leading the country to free elections, was announced. Then a demonstration held on 22 November 1989 attended by 100,000 citizens brought support for the demands of the political movement, and by the end of November the Bratislava VPN centre had registered two million visitors.

Thus, 17 November 1989 marks the beginning of the period of decommunization of the political system in Czechoslovakia, involving two parallel processes. The former (Cibulka et al., 2014: 45) is a return to the standards of democracy effective in the 1940s; the latter concerns redefining within the democratic order the relations between the Czechs and Slovaks in a new federation.

The first legal and constitutional changes in Czechoslovakia were introduced by partial amendments to the existing laws and then by way of detailed acts, starting with the deletion on 29 November 1989 of the clause stipulating dominant role of the communist party, ${ }^{1}$ and subsequently followed by the Act of 16 March

\footnotetext{
${ }^{1}$ Ustawny zakon ć.135/1989 Zb. z 29. novembra 1989.
} 
1990 on elections ${ }^{2}$ to the Slovak National Council (Slovak: Slovenskej narodnej rady, SNR), change of the name of the state, effected on 29 March 1990, to the Czech and Slovak Federative Republic (Slovak: Ćeska a Slovenska Federativna Republika, ĆSFR), ${ }^{3}$ and the removal on 18 April 1990 of the provision on the dominance of socialism from the preamble to the Constitution ${ }^{4}$.

In the parliamentary elections to the House of People (Snemovna lidu) in 1990, the Slovak Public Against Violence (VPN) gained 32.5\% of the vote, whereas the Czech Civic Forum (Czech: Obćanske forum, OF) led by Vaclav Havel secured $53.1 \%$ of the vote.

Following the elections, a coalition cabinet headed by Slovak Milan Čalfa from VPN was formed at the federal level. It included the Czech Civic Forum, the Slovak Public Against Violence (VPN) and the Christian Democratic Movement (Slovak: Krest'anskodemokraticke hnutie, KDH). The cabinet had almost 65\% support and was dominated by the Civic Forum which controlled as many as $40 \%$ of the seats in the Parliament. Within less than 2 years, both forum-type political groups went through a fragmentation process. Thus by the end of 1991, the ruling coalition had increased to five political parties, including three Czech: the Civic Democratic Party (Czech: Obćanska demokraticka strana, ODS), Civic Movement (Czech: Obćanske hnuti, $\mathrm{OH}$ ) and the Civic Democratic Alliance (Czech: Obćanska demokraticka aliance, ODA). The composition of the Slovak parties in the coalition did not change, although a split occurred within VPN.

The 8-9 June 1990 elections in Slovakia, with 16 political groups vying for the seats, represented in fact a clash between the authoritarian ancien régime and the emerging competitive political environment promoting the standards of freedom and democracy, parties re-established from the 1940s and newly formed groups. The winning election committees formed the first hybrid club of parliamentary parties consisting of the Public Against Violence and, within its framework, the Hungarian Independent Initiative (Mad'arska nezavisla iniciativa, MNI), the Christian Democratic Movement, the Slovak National Party (Slovak: Slovenska narodna strana, SNS), the Democratic Party (Slovak: Demokraticka strana, DS), a Slovak formation of the Communist Party of Czechoslovakia (Slovak: Komunisticka strana Ćeskoslovenska, KSĆ), a coalition of Hungarian formations Coexistence and the Hungarian Christian Democratic Movement (Slovak: Spoluzite-Mad'arske krest'anskodemokraticke hnutie, S-MKDH) and the Slovak branch of the Czechoslovakian Green Party (Czech: Strana zelenych, SZ).

2 Zakon Slovenskej narodnej rady zo 16. marca 1990 o vol'bach do Slovenskej narodnej rady. $\mathrm{Sb}$ ć80/1990.

${ }^{3}$ Ustavny zakon ć. 81/1990 Zb. z 29. marca 1990; ustavny zakon ć.101/1990 Zb. z 20. aprila 1990.

4 "[Z]ruśenie preambuly ustavy, ktora wyhlasovala, że socializmus w naśej krajine zvitazil" in: Ustavny zakon ć. 100/1990 Zb. z 18. aprila 1990. 
As a result of the elections, an anti-communist coalition cabinet was formed. It consisted of the Public Against Violence with the Hungarian Independent Initiative (led by Bela Bugar), the Christian Democratic Movement and the Democratic Party. Milan Čič served as prime minister of the first democratic Slovak government. Vladimir Mečiar, ${ }^{5}$ who had entered the inner circle of the Velvet Revolution after joining VPN, became one of the ministers in the government. Earlier, on 11 January 1990, upon recommendation of the icon of the Velvet Revolution, Alexander Dubček, ${ }^{6}$ Mečiar became a cabinet member of the noncommunist government ${ }^{7}$ running the Ministry of the Interior and Environment.

With his wealth of experience of authoritarian regimes enhanced by being a member of the new establishment, Vladimir Mečiar had a great deal of political capital. The new rules in the process of exercising power in the conditions of political rivalry posed great challenges to the emerging political class that was then developing its own pioneering styles of governance. These factors played a particularly important role given its lack of proper democratic experience. Moreover, it should be noted that it could rely on the styles formed in the 1940s to only a limited extent in the new geopolitical system.

In the first few months after the government took office, the first conflict within the ruling party occurred between Mečiar, the prime minister and a member of VPN, and Fedor Gal. F, the chairman of the VPN Coordination Center. Gal's efforts resulted in the resignation of Prime Minister Mečiar, who subsequently, on 5 March 1991, formed a faction within VPN - Movement for Democratic Slovakia (Slovak: Hnutie za demokraticke Slovensko, HZDS). Insofar as VPN was a modernizing group from the anti-communist opposition, HZDS at the time of its creation had a populist character with a left-wing orientation declaring its support for the federal structure of the Czechoslovak state and the provision of full social protection during the economic reforms. In a short time, HZDS attracted a large part of the membership base of its former party. Following the secession of HZDS, VPN merged with the Civic Democratic Union (Slovak: Obćianska demokraticka unie, ODU) headed by Martin Porubjak in April 1991.

${ }^{5}$ Vladimír Mečiar was born on 26 July 1942 in Zvolen. After graduating from secondary school in 1959, he started working as a clerk, then as a secretary, at the Poviat National Council in Žiar nad Hronom. In 1962, he joined the Communist Party of Czechoslovakia (KSĆ) and from 1967-1968 he was the chairman of the Regional Committee of the Czechoslovak Youth Union. He was expelled from the party in 1970 for criticizing the invasion of the Warsaw Pact forces in August 1968. Then he worked as a smelter in a factory in Dubnica nad Váhom. He studied at the Faculty of Law at the Comenius University in Bratislava on a part-time basis until 1975. In 1990 he obtained a $\mathrm{PhD}$ in legal sciences.

${ }^{6}$ https://sk.wikipedia.org/wiki/Vladimír_Mečiar (accessed 15.02.2019).

7 Although Čič's government formed on 12 December 1989 was nominated as non-communist, it consisted of 10 communists and 11 opposition activists mainly from VPN, numerous former KSĆ members. 
The reorganized cabinet consisted of the remnant members of VPN, the Hungarian Independent Initiative and the Christian Democratic Movement (KDH) which was set up on 30 November 1989 as a result of a merger of Christian Democratic clubs clubs (Kopeček, 2007: 305). The Christian Democrats defined themselves as a nationwide ecumenical political movement which aims to build a fair, spiritually healthy and economically vibrant society. As regards the economy, it advocated a shift towards a market economy, yet ensuring the provision of social protection. With reference to the system of the state, it opted for a grassroots agreement to be reached by the two republics in which they would form a federation, but each would implement its independent foreign policy. Moreover, the coalition also included the Democratic Party (Slovak: Demokraticka strana, DS) (Kopeček, 2007: 363) promoting promoting the ideology and policy of the continuation of its predecessor (established before 1948).

The government coalition was informally supported by the pro-Hungarian Coexistence Party (WSEZ) acting for democracy and the rights of national minorities. The largest opposition group of the Slovak Parliament was the Slovak National Party (SNS), established in December 1989. The party opted for pro-market policy, took a pro-social stand in social policy; and as regards the systemic issues, it advocated parliamentary democracy and strongly supported the sovereignty of the Slovak Republic. The party displayed divisive tendencies which led to the creation of the grotesque Slovak National Unity (Slovenska narodna jednota, SNJ) after the departure of extreme radicals headed by Stanislav Pánis.

The Communist Party of Slovakia held a peripheral position in the first democratic parliamentary system (as a territorial organization of the Communist Party of Czechoslovakia). KSS changed its name to the Communist Party of Slovakia - the Democratic Bench Party (Slovak: Komunisticka strana Slovenska-Strana demokratickej L'avice, KSS-SDL') at a party congress held on 20 October 1990. It continued with further modernization (after leaving the federal Communist Party of Bohemia and Moravia) to declare itself to be a social democratic force founded on the tradition of the progressive left aiming to build a democratic, humanist and socially fair society by combining market economy with social security. On 1 February 1991, it changed its name to the Democratic Bench Party (Slovak: Strana demokratickej l'avice, SDL').

The weakest entity of the parliamentary system was the Green Party (Strana Zelenych, SZ) founded at the end of the 1980s as an independent civic initiative movement for nature protection. It stood in the 1990 elections as an independent Slovak branch of the federal Green Party (Strana Zelenych, SZ). In 1991, it was registered as a separate Green Party in Slovakia (Strana zelených Slovenska, SZS).

The support given by the Hungarian parties allowed the existing coalition under the leadership of J. Čarnogurský, who replaced V. Mečiar as the prime minister on 23 April 1991, to continue the reform process. The government stayed in power until the new parliamentary elections; this was despite a crisis 
within $\mathrm{KDH}$, from which a radical national wing led by Jan Klepać split off to form the marginal Slovak Christian-Democratic Movement (Slovak: Slovenske krest'ansko-demokraticke hnutie, SKDH).

The functioning of the first democratic party system was marked by the tremendous dynamics of change stemming from the accelerated process of "adopting" the democratic political culture by people and institutions: the ruling camp and the opposition alike. The political parties grew in number from the start of the term due to the processes of adjusting the structure of the party system to the changing network of the group interests of the civil society which was being overhauled. Ideological, policy and organizational changes of political parties, splits and secessions should be regarded as natural in the process of the replacement and circulation of political elites (including in particular party elites). Personal changes for the most part produced positive organizational and, more importantly, political effects, enhancing the political agenda. One such example was the emergence of the radical-separatist Slovak Democratic and Christian Union (Slovak: Slovenska democraticka a krest'anska unie, SDKU) from the KDH, which subsequently changed its name to the Christian Social Union of Slovakia (Slovak: Krest'anskosocialna Slovenska Union, KSU), with the principal aim of Slovakia gaining national sovereignty and leaving the Czech-Slovak Federation. Jan Klepač became the leader of the group.

The fragmentation of the party system during the government's first term of office was a consequence of varying stances on the change of the political and economic system, attitudes towards the previous system, including the ancien régime party, and the choice between Slovak self-determination and Czech-Slovak federalism. The new challenges subjected all the political parties to shocks and disintegration to a varying degree, nonetheless, most managed to regain balance and maintain political influence, allowing the system to sustain balance and function until the end of the term.

\section{A competitive party system with a dominant Movement for Democratic Slovakia}

In the 1992 elections, only 5 out of 23 election committees entered parliament. The reason for the decrease in the number of parliamentary parties was the amendment to the electoral law $^{8}$ which raised the electoral threshold for coalition electoral committees to $5 \%$, which resulted in an increase of $23.8 \%$ of "lost" votes cast for parties that did not enter parliament (among others, the liberal-democratic SD or ODU; the latter in consequence adopted a resolution on self-dissolution).

${ }^{8}$ Zákon Slovenskej národnej rady z 26. februára 1992, ktorým sa mení a dopín̆a zákon Slovenskej národnej rady č. 80/1990 Zb. o vol'bách do Slovenskej národnej rady. 
The Movement for Democratic Slovakia won the elections with $37.26 \%$ of the vote and 74 parliamentary seats, choosing to form a one-party minority government. Prime Minister V. Mečiar counted on the support of the Slovak National Party (SNS) without a coalition agreement, appointing SNS leader Ludovit Černák as the Minister of Economy.

HZDS's electoral success and the ease of forming a government overshadowed efforts aimed at broadening the social base of governance and creating a majority coalition. The dominant role of HZDS in the country was confirmed by the election of the first president of the Slovak Republic, Michal Kováč, designated by HZDS and enjoying the support of SNS (demanding in return the position of the minister of defence to be appointed to a civilian not associated with the communist military establishment). For the sake of certainty, SNS put in a request that a coalition agreement be signed. A similar proposal was made by SDL which supported the minority government informally. In the absence of a response from the ruling party, both parties withheld support for the government and Minister Černák resigned. The loss of support for the minority government and internal cabinet perturbations further weakened the ruling camp. Such a blow stemmed from the conflict-provoking commanding leadership style and personnel policy pursued by the prime minister. The first personal conflict between Prime Minister Mečiar and the deputy chairman of HZDS and the Minister of Foreign Affairs, Milan Kňažko (Barański, 1995: 70-72), led to the minister's resignation on 19 March 1993. On the same day, the president also accepted the resignation of the coalition Minister of Economy Ludovit Černák. The reason for that resignation and, as a consequence, the Slovak National Party joining the ranks of the opposition was V. Mečiar's decision to appoint former communist Imrich Andrejčák as Minister of National Defense, which violated the coalition agreement.

As a consequence of the personal conflict between M. Kňažko and V. Mečiar, the unwelcome minister left HZDS and formed the Alliance of Democrats of the Slovak Republic (Slovak: Alianci demokratu Slovenske republiky, ADS) in November 1993. Kňažko took with him 7 MPs from HZDS, starting a new parliamentary club opposed to the government.

The one-party, minority (66 seats) HZDS government survived on its own for over half a year. At the same time, HZDS politicians held talks on coalition cooperation with the opposition SDL and the Slovak National Party. The negotiations with the social democrats did not go beyond the level of negotiations, whereas the talks with SNS had a positive outcome in that the conclusion of the coalition agreement on 19 October 1993 led to the strengthening of the government.

The retaining of power by the minimally victorious coalition with the nationalists was accompanied by the polarization of the political scene caused by the divergence of opinions on economic reforms (in particular privatization) and the issue of choosing between the sovereignty of Slovakia or the modernization of the federation. Concurrent with the cross-party program debate, further changes 
within the government took place leading primarily to an internal weakening of HZDS. In February 1994, Foreign Minister Jozef Moravčik was forced to resign and upon removal from office, following the steps of his predecessor, launched his own political initiative, an eleven-person platform - An Alternative to Political Realism (Slovak: Alternativa politickeho realismu, APR).

To counterbalance the disintegration of the political scene, a merger between the Alliance of Democrats (Slovak: Aliancie demokratov, AD) and an Alternative to Political Realism (APR) occurred, forming the Democratic Union of Slovakia (Slovak: Demokraticka unia Slovenska, DUS).

Slovakia's economic problems: high inflation and unemployment, economic recession; constant changes within the power apparatus; as well as problems with the Hungarian minority; led to dissatisfaction and criticism of the government, prompting the leader of the Christian Democratic Movement (KDH) J. Čarnogurský to submit a motion for a vote of no confidence in the government, which was accepted by the Parliament.

In mid-March 1994, a coalition minority government (71/150 MPs) was formed, led by J. Moravčik, consisting of MPs from the Democratic Union of Slovakia, the Democratic Bench Party (SDL), the Christian Democratic Movement, the National Democratic Party. This coalition was also informally supported by a coalition of Hungarian parties and five independent MPs. Despite the program differences between the coalition partners representing a wide range of political options from the centre-right, through the Christian Democrat-Liberal party to the post-communist party, the cabinet survived until the next elections (Barański, 2004: 150). The shortened term of the Parliament (1992-1994) was marked by the greatest polarization of the political scene since the beginning of the political transition. Due to numerous divisions and secessions, the number of parliamentary parties and clubs increased from 5 to 9 . The changes in the Slovak party system mostly affected the governing coalition parties (HZDS and SNS).

A secession within SNS led to the emergence of the National Democratic Party - New Alternative (Slovak: Narodnodemokraticka strana-Nova alternativa, NDS-NA). In response to the Slovak National Party rejoining the coalition with HZDS, its leader Ludovit Černak formed a 5-person Club in the Parliament of independent MPs of the National Democratic Party in March 1994.

Under a similar scenario - leaving the SDL ranks - the Workers' Association of Slovakia (Slovak: Zdrużenie robotnikov Slovenska, ZRS) was established. The protest of a group of activists of the post-communist social democracy against the liberalization of the party resulted in its shift to the positions held by the radical left, focused on protecting working people in the process of economic transformation.

On the whole, the second term of the Slovak Parliament was dominated by personal conflicts, ideological crises within the party and secession processes, as well as the formation of new parliamentary groups and the emergence of minority governments with hybrid structures. 


\section{HZDS dominance in the conflict-ridden and polarized political system}

The first elections to the newly sovereign National Council of the Slovak Republic (Slovak: Narodna rada Slovenskej republiki, NRSR) was won by the coalition Movement for Democratic Slovakia and Farmers' Party of Slovakia (Slovak: Koalicia Hnutie za demokraticke Slovensko a Rol'nicka strana slovenska, HZDS-RSS), winning the support of 35\% of voters and thus confirming its dominant position in the Parliament. V. Mečiar was appointed prime minister for the fourth time. He invited ZRS (7.34\%) and SNS (5.40\%) to participate in the creation of a government coalition which commanded a narrow majority of 83 seats in the 150-member parliament. The opposition consisted of the four-party coalition Joined Choice (Slovak: Spoloćna volba, SV) made up of the Democratic Bench Party (SDL'), the Social Democratic Party of Slovakia (Slovak: Socialnodemokraticka strana Slovenska, SDSS), the Slovak Green Party and the Movement of Farmers of the Slovak Republic (Slovak: Hnutie pol'nospodarov Slovenskej Republiky, HPSR) winning 10.4\% of the vote, and the Hungarian Coalition (Mad'arska koalicja, MK) including the Hungarian Christian Democratic Movement (MKDH), the Hungarian Citizens Party (Slovak: Mad'arska obćianska strana, MOS) and Coexistence Party (WSSE) which secured $10.2 \%$ of the vote. The opposition benches were also filled by KDH with $10.1 \%$ support and the Democratic Union of Slovakia, gaining $8.6 \%$ of the vote.

The ruling coalition was to a large extent consistent as regards its views and actions to be undertaken in order to slow down the liberal reforms while strengthening the role of the state in economic and social policy. On the other hand, being ideologically more diversified than the government coalition, the opposition was united by the will to continue market reforms and build a civil society by limiting the omnipotence of the state, stopping the process of breaking the constitution and suspending the political war declared on the opposition by the ruling camp. A significant factor that fuelled the conflict between the coalition and the opposition was the authoritarian style of politics, dominated by the personality of V. Mečiar, who "turned" his charisma into the style of an overbearing doctrinaire.

\section{Violation of the rules of the democratic legal state}

The ruling coalition resorted to adopting laws which were in breach of the Constitution in terms of restrictions on civil liberties (including freedom of speech), freedom of association and the exercise of the parliamentary mandate. The most glaring action was the rejection by the parliamentary majority of the decision reached by the Constitutional Court stating that depriving two MPs from the 
government coalition of their parliamentary mandate for resigning from their party (HZDS and SNS) was incompatible with the constitutional principle of understanding the parliamentary mandate. The ruling camp went as far as limiting the rights of the opposition, monopolizing access to the media, and organizing and using state institutions to discredit political opponents by means of negative campaigning. The operations of the ruling coalition were also directed against the president, sparking off the most serious political crisis of that period related to the kidnapping of President M. Kovać's son which allegedly was the result of a conspiracy by the secret services and Prime Minister Mečiar. The Slovak version of "the war at the top" consisted of limiting funds allocated to the presidential office by the parliamentary majority, conducting psychological warfare with the president, accusing him of treason and demanding several times that he leave office.

The authoritarian style of politics within the ruling coalition and in relations with the opposition as well as the arrogance towards the president devalued the previous achievements of the entire political class and went well beyond internal policy contributing to a delay in Slovakia's accession to NATO and the European Union (Cichosz, 2010: 115-121). As a result, the political landscape of Slovakia in the second half of the fourth term of V. Mečiar's government met the standards of a hybrid regime on the border between democracy and authoritarianism (Kopeček, Spáč, 2010: 117), with Vladimir Mečiar as its main spiritus movens, whose surname was used to coin the term „Mečiarsm” to denote a clash of democratic and authoritarian values and systems, a differentia specifica of the political system in Slovakia in 1990-1998.

\section{Formation of the opposition Blue Coalition}

The opposition reacted to the authoritarian policy of the prime minister and the government by forming in the autumn of 1996 the so-called Blue Coalition which included the centre-right parties DS, DU and $\mathrm{KDH}$. Its purpose was to build a platform for the development of methods of joint action and the coordination of non-parliamentary political actions aimed at returning the country to democratic standards, restoring effective control over executive power by the opposition parties, and ensuring that the secret services were not used by the government in political disputes.

The preparations for the rivalry between the opposition and the ruling camp led to the formation of the Slovak Democratic Coalition (Slovenska demokraticka koalicja, SDK) in July 1997 and extending the Blue Coalition by the Social Democrats (SDL) and the Green Party. Deputy head of the Christian Democrats Mikulaś Dzurinda became the leader of SDK.

In their fight against Mečiarism, the parliamentary opposition began collecting signatures on a petition for a referendum on introducing a constitutional 
amendment to lay down a principle that the president be elected in general elections. That was to prevent the scenario of Prime Minister Mečiar taking over the presidential powers in the event where no joint candidate managed to collect 76 votes. The referendum on the constitutional change in the rules for electing the president was extended on the initiative of the government to include a proposal concerning Slovakia's accession to NATO, which gave rise to greater scepticism among the citizens than the issue of the direct election of the president and could have contributed to maintaining the status quo, as expected by the Mečiarites.

Seeking to boost its chances of electoral success a few months before the elections, the government put forward a legislative initiative to amend the electoral law on electoral coalitions. Under the new initiative, each electoral group within a coalition would be required to exceed the threshold of $5 \%$ of all votes, which posed a big risk of blocking the institution of electoral coalition altogether. Nonetheless, the political parties found a solution to that problem by transforming a coalition into "electoral" political parties. The Slovak Democratic Coalition and the Hungarian parties pursued that path forming the Hungarian Coalition Party (Slovak: Strana mad'arskej koalicie, SMK). Prior to the elections, the anti-Mečiar camp was strengthened by the Party of Civic Understanding (Strana obćianskeho porozumienia, SOP) established in February 1998 and led by its founder, a very popular Košice mayor, Rudolf Schuster. SOP advocated the democratization of the Slovak political scene, distancing itself from the "undemocratic" politics of HZDS and its coalition partners, declaring a pro-Western course and support for the "Coalition".

A characteristic feature of the party system of the third term of office was the substantive and organizational consolidation of the anti-Mečiar opposition. At the beginning of June 1998, the first meeting of the leaders of the Slovak opposition took place and the principles of cooperation between the democratic forces, following the autumn parliamentary elections, were formulated. The first "opposition round table" initiated by the Slovak Democratic Coalition (SDK) was attended by the leaders of the Hungarian Bloc, the Slovak Democratic Left, the Christian Democratic Movement and representatives of trade unions, the third sector and student unions.

The integration of the opposition against the government coalition proved to be sustainable during the pre-election campaign and in the process of forming a new government coalition. The 1998 elections brought a Pyrrhic victory to HZDS which was in fact defeated by the parties of "the Blue Coalition". They won 93 seats in the National Council of the Slovak Republic and formed a government of a broad democratic coalition composed of the Slovak Democratic Coalition (SDK), the Democratic Bench Party (SDL'), the Hungarian Coalition Party (SML) and the Party of Civic Understanding (SOP). SDK leader Mikuláš Dzurinda became the Prime Minister of the majority coalition. The opposition benches were filled by HZDS and the Slovak National Party. 
The fourth term of office (1998-2002) was difficult from the perspective of both domestic and international affairs. The dynamic process of privatization ground to a halt at the halfway point of the term; no significant economic growth was achieved and the unemployment rate began to rise sharply (only to drop slightly afterwards). The difficult economic situation becomes the dominant subject of socio-political debate shifting the dispute between Mečiarism and anti-Mečiarism further down the agenda. The socio-economic problems became the axis of the socio-political divisions that led to the fragmentation of the party system as a result of conflicts and splits in almost all the political groups, except the Hungarian Coalition Party (SMK). The program and organizational crisis that affected almost all the parliamentary parties did not hinder the formation of a broad democratic coalition with a high level of relevance, indicating Slovakia's path to becoming a consolidated democracy.

\section{Conclusions}

The Czechoslovakian "Velvet Revolution" led the society of the Czech Republic and Slovakia to build the foundations for the democratic system, putting an end to the authoritarian regime by conducting the first democratic parliamentary elections to the parliaments of the federation and the Czech Republic and Slovakia, with very high turnout exceeding 95\% of eligible voters. The high turnout in Slovakia dropped to $76 \%$ in 1994 only to rise to over $84 \%$ in the elections between the antagonistic groups: the dominant Mečiar circle and the democratic "blue opposition".

The "replacement" of old elites with new ones formed in the process of competitive elections should surely be considered a democratic phenomenon, as opposed to a displacement whereby the pro-reform ancien regime elites join the democratic transformation. A positive development was also the upholding of the democratic traditions from the interwar Czechoslovakian period during the formation of new political parties. Notably, a positive feature of the competitive party system was the maintenance of a balance between the confrontational "Mečiar" parties and democratic opposition groups.

The negative features of the reverse wave include first of all the ambivalent attitude to liberal values, in particular in economics. The processes of privatization, the introduction of a market economy, and Slovakia's entry into the eurozone were all treated as sensitive issues to be used in the political struggle against liberal and central groups. Economic liberalism was not the subject of political manifestos and, in the opinion of the ruling camp, it was not associated with democracy or the postulate of the demo-liberal state. Another negative feature defining the rule of the Movement for Democratic Slovakia was the domination over the coalition 
parties achieved by an arbitrary personnel policy based on loyalty, obedience and opportunism. The dominance of the ruling coalition subsequently shifted to the parliament, whose legislative function was subordinated to the interests of the ruling camp, seeking to amend and manipulate the law; numerous breaches of the law were then committed to create the conditions favourable for re-election (for instance, amendments to the electoral law). The omnipotence of the state was on the rise as it took control over many public affairs inherent in other administrations, including local government.

Government administration and its agencies pursued an administrative and political policy and dealt with other state organs (e.g. the president of Slovakia) and public mass media in a manner conducive to further state omnipotence. The third term of office of the HZDS government reached the level of a hybrid regime on the border between authoritarianism and democracy leading to a political crisis which was resolved only after the 1998 parliamentary elections. The victory of the broad front of democratic forces forming the "blue coalition" and the creation of a broad parliamentary coalition created the conditions for the introduction of constitutional changes, thus raising the democratic standards of the election of the president by means of a general election; the introduction of supra-municipal national self-governments; active Euro-Atlantic policy of political and military integration within NATO; and integration with the economies of Western European countries.

\section{References}

Ágh, A. 1998. The Politics of Central Europe. London, Thousand Oaks, New Delhi: Sage Publications.

Antoszewski, A., Fiala, P., Herbut, R., Sroka, J. (eds.). 2003. Partie i systemy partyjne Europy Środkowej. Wrocław: Wydawnictwo Uniwersytetu Wrocławskiego, pp. 145-160.

Balík, S., Hloušek, V., Holzer, J., Šedo, J. 2007. Politický systém českých zemi 1848-1989. Brno: Mezinárodní politologický ústaw.

Barański, M. 2004. Zmiany systemu partyjnego w Słowacji. In: R. Fiedler (ed.). Integracja europejska na początku XXI wieku. Wybrane problemy. Poznań: Wydawnictwo Uniwersytetu Adama Mickiewicza.

Barański, M., Czyż, A., Kubas, S., Rajczyk, R. 2016. Wybory, prawo wyborcze, systemy wyborcze w państwach Grupy Wyszehradzkiej. Katowice: Wydawnictwo Uniwersytetu Śląskiego.

Barański, M. (ed.). 1995. Dynamika systemów politycznych wybranych państw Europy Środkowej $i$ Wschodniej. Katowice: Wydawnictwo Uniwersytetu Śląskiego.

Barański, M. (ed.). part. E. Pioskowik. 2005. Systemy polityczne państw Europy Środkowej $i$ Wschodniej. Ustrój, organy władzy, partie polityczne. Katowice: Wydawnictwo Uniwersytetu Śląskiego. 
Beyme von, K. 1984. Systemwechsel in Osteuropa. Frankfurt am Main: Suhrkamp.

Chmielewski, G. 2014. System konstytucyjny Stowacji. Warszawa: Wydawnictwo Sejmowe.

Cibulka, L. et al. 2014. Ústavné právo. Ústavný systém Slovenskej republiky. Bratislava: Vyd. Univerzita Komenského.

Cichosz, M. 2010. Gabinety na Słowacji po 1990 roku. In: E. Pałka (ed.). Współczesna Słowacja. Sytuacja wewnętrzna i pozycja międzynarodowa. Wrocław: Oficyna Wydawnicza Arboretum, pp. 133-150.

Czyż, A., Kubas, S. 2012. Czechy i Słowacja. Politologiczne studium wspólnej i oddzielnej państwowości. Katowice: Wydawnictwo Uniwersytetu Śląskiego.

Czyż, A., Kubas, S. 2014. Państwa Grupy Wyszehradzkiej: pomiędzy przeszłościa a teraźniejszością. Wybrane aspekty polityki wewnętrznej i zagranicznej. Katowice: Wydawnictwo Uniwersytetu Śląskiego.

Huntington, S.P. 1995. Trzecia fala demokratyzacji. Warszawa: Państwowe Wydawnictwo Naukowe.

Kitschelt, H. 1995. Formation of Party Cleavages in Post-Communist Democracies. Theoretical Propositions. Party Politics 1(4), pp. 447-472.

Kitschelt, H. et al. 1999. Post-Communist Party Systems Competition, Representation, and Inter-Party Cooperation. Cambridge: Cambridge University Press.

Kopeček, L. 2007. Politické strany na Slovensku 1989 až 2006. Brno: Centrum pro studium demokracie a kultury.

Kopeček, L., Spáč, P. 2010. System partyjny Słowacji. In: E. Pałka (ed.). Współczesna Słowacja. Sytuacja wewnętrzna i pozycja międzynarodowa. Wrocław: Oficyna Wydawnicza Arboretum, pp. 111-133.

Muller, J. 2017. Co to jest populizm? Trans. M. Sutowski. Warszawa: Wydawnictwo Krytyki Politycznej.

Posluch, M., Cibulka, L'. 2006. Štátne právo Slovenskej republiky. Šamorín: Heuréka.

Rolková, N. 2004. Desatročie Slovenskej Republiky: venované jubileu štátnej samostatnosti. Martin: Matica slovenská.

Rychlík, J. 2002. Rozpad Československa: česko-slovenské vztahy 1989-1992. Bratislava: Academic Electronic Press.

Snyder, T. 2017. O tyranii. Dwadzieścia lekcji z dwudziestego wieku. Trans. B. Pietrzyk. Kraków. Społeczny Instytut Wydawniczy Znak.

Szomolanyi, S., Meseznikov, G. (eds.). 1994. Slovensko-volby 1994: príčiny, dôsledky, perspektívy: zborník z vedeckej konferencie, ktorá sa konala 9. novembra 1994 v Bratislave. Bratislava: Slovenské združenie pre politické vedy: Nadácia Friedricha Eberta.

Wojnicki, J. (ed.). 2015. Kształtowanie ładu demokratycznego w państwach Europy Środkowej i na Bałkanach. Szanse i zagrożenia. Warszawa: Aspra.

Wojtas, K. 2011. Partie populistyczne w Czechach i na Stowacji. Warszawa: Wydawnictwo Naukowe SCHOLAR.

\section{Additional sources}

HZDS website, http://www.hzds.sk

KDH website, http://www.kdh.sk/

KSS website, http://kss.sk/ 
MOST-HID website, http://www.most-hid.sk

NOVA website, https://www.nova.sk

OL'aNO website, http://www.obycajniludia.sk/

SAS website, http://www.sas.sk

SDKU-DS website, http://www.sdku-ds.sk

SIET website, http://siet.sk

SME-RODINA website, http://hnutie-smerodina.sk

SMER website, http://www.strana-smer.sk

SMK website, https://www.mkp.sk

SNS website, http://www.sns.sk/

STRANA ZELENYCH website, http://stranazelenychslovenska.sk 